\title{
Chinese Rural Bribery: The Plight of Rural Grass-Root Democratic Autonomy
}

\author{
Sufang Qin \\ Jinan University Public Management School, Guangzhou, China \\ Email: 990511883@qq.com
}

How to cite this paper: Qin, S.F. (2016) Chinese Rural Bribery: The Plight of Rural Grass-Root Democratic Autonomy. Journal of Human Resource and Sustainability Studies, 4, 337-345.

http://dx.doi.org/10.4236/jhrss.2016.44032

Received: August 17, 2016

Accepted: December 26, 2016

Published: December 29, 2016

Copyright $\odot 2016$ by author and Scientific Research Publishing Inc. This work is licensed under the Creative Commons Attribution International License (CC BY 4.0). http://creativecommons.org/licenses/by/4.0/

\begin{abstract}
Rural autonomy is playing an important part in the rural grass-root democratic construction. Rural bribery is becoming one of the main barriers in new Socialist Countryside Construction, which gets the grass-root democratic autonomy in puzzledom. The paper is based on the experience of two different villages-G village in Inner Mongolia and $\mathrm{Y}$ village in Shanxi province, inducing and organizing the explanatory reasons and solving projects of rural bribery by researchers in recent years in doctrinal angle, discussed separately from the perspectives of institution study, economics and social capital theory. It tries to compare the advantages and disadvantages of various ways to establish a comprehensive governance framework for rural bribery.
\end{abstract}

\section{Keywords}

Rural Bribery, Grass-Root Democratic, The Plight of Construction

\section{Introduction}

After 30 years reforming, under the background of social transformation, the government reinforces the importance of the "three rural issues"; our country rural area has made significant progress in the political democratization, economic marketization, etc. In the early 80 s, rural autonomy became important results of implementation of grassroot democratic in our country, and democratic election is the important embodiment of basic level autonomy. In recent years, the phenomenon of unfair and shortcomings in rural elections have been explored by the network media in our country; rural bribery has been front in the rural elections and governance, and become the main culprit of destruction of democracy at the grass-root democratic. Rural bribery repeated emergence and became a bone sticking in the rural governance with the advancement of urbanization process in China in recent years. Therefore, how to curb rural bribery in the 
general election in the countryside, and ensure that voters have the right to vote and be elected fairly and openly, and guarantee the construction of socialism new countryside to preserve the rural collective interests, have become the important exploration direction of scholars.

This article selects domestic scholars in recent years about some cause analysis and countermeasures, analyzes the advantages and flaws of all kinds of views during the process of rural election in our country, and rationally explores the application of various ways, in order to help more for fully studying rural governance.

\section{Several Theoretical Interpretation of Rural Bribery Troubled}

In our country, facing bribery behavior in the public organization, ordinary citizens generally adopt the way of report or petition to terminate violation behavior, if the way is blocked, citizens would be expected to replace the current beneficiary of bribery by voting rights in the next general election including rural. When the impeach petitions cannot effectively safeguard the collective rights, many village residents put all their hopes in the next general election. We call this approach "opportunistic" victory. Made it difficult for many of the villagers to accept the term of bribery phenomenon win in such a split of "opportunistic" victory. The failures to prohibit bribery phenomenon has seriously restricted the reasonable interest expression and legitimate political demands of farmers during the construction of "three agriculture". Bribery behavior has become a significant cause that damaged Socialist Democratic Politics with Chinese Characteristics. Rural grassroots election is caught in a dilemma of bribery, on the one hand, reflects the interests of all parties in the process of state transition; On the other hand, reflects Informal disadvantages during the process of the grass-root democratic construction in our country countryside democracy [1]. The situation that violates the logic and justice is not alone in the process of rural governance. the main reasons that the rural bribery troubled are that the definition vote buying errors in current laws and the comprehensive system specification, and the long-term development of the rural economy is blocked and fault and lose of social capital chain in the process of the rural autonomy.

1) The interpretation of the system of socialism: the lack of perfect definition by law

In 2005 Ministry of Civil Affairs in Economic Daily defines vote buying as a behavior that candidates and their friends and relatives directly or instigating others to bribe village voters, election staff or other candidates with money, property or other benefits [2]. Some scholars think this definition has the obvious flaw. Limiting vote buying in a narrow concept framework, so that making vote buying proceeds in many time and aera. Some of these "temptation" show the direct property, or in the name of the collective emotional contact dinner banquets near the election day, or promise after the voters and its relatives enjoy the benefits of "special" and so on. In the process of rural letters and acquisition, we found that the phenomenon by villagers report that village cadres reappointment in the village committee elections by vote buying means is not rare. In the research (visited 80 villagers for the record) of Xinzhou city, Shanxi Province Y 
village villagers (citizens have voting rights), $48 \%$ of the villagers said themselves or relatives and friends have been the temptation of candidate "benefits" of village cadres in the past, $35 \%$ of the villagers said they heard around the adjacent had similar experience, even the local people who working outside throughout the year also believe that vote buying phenomenon are a lot.

During the research, Baotou city a $G$ village villager said privately, as long as the family of five give their votes to a candidate, their illegal grazing would be neglected in the future.

According to the "system construction" of the new system, system is a set of constraints that constraint people's daily life behavior. A certain system builds a certain behavior. Oliver-Williamson thought "system of details" [3] is important. He thought that whether a balanced improved the status of stakeholders will depend on the particular system structure. People's behavior follows the social operation rules. Law act as a society guider, it gives the identity, the resources, the goals and strategy to the social man. But the definition of vote buying by law is lack of accuracy, thus it fall into the governance dilemma. In the process of democracy at the basic level of autonomy, the primary defect is lack of perfect system.

2) The explanation of economics: direct inducements

Some researchers said the more impoverished place, the more prone to vote buying [4]. First, ignoring the motivation of these local candidates, for the economy relative to other poorer areas, people can be gained by less cost of bribery vote in local voters, of course, these costs are not simply means money bribery. When we researched Xinzhou city, Shanxi Province Y village, candidates even sometimes using "a basket of eggs" can get some voters support and his families. In the village of the economy is relatively backward, the reason why people showed low enthusiasm and sense of responsibility in the village committee election matters is that they widely believed that when they were "for sale" votes could earnings more benefits. In 2001, Ji County, Shanxi Province popped up the shocked bribery case of magistrate just reflected this, the candidate bribed the 39 people's congress with only 19,500 yuan. Xinzhou city Y village is a national poverty village, widowed old man and the left-behind women and children are more, more than $80 \%$ of the 65 -year-old man received ranging from 80 - 150 benefits a month from government. The village per capita income situation as shown in Figure 1 thought researching. Supposing someone conduct vote buying, and buy each vote with 50 yuan, then 102 people whose annual income less than 1500 yuan people will be the object of potential of bribery, because their hand worth $\$ 50$ votes is worth half a month of income. From this point, rural bribery and the rural backward economy problem presents the obvious correlation.

Since the problem of vote buying restricts the development of democratic autonomy, it must be solved. Some people believe that rural relative to the city lacks strong economic support, so the farmers' rights protection awareness and participation are greatly lags behind the urban people, which is the direct cause of the vote buying existing a large amount for a long time. So quite a few scholars put forward to develop the rural 


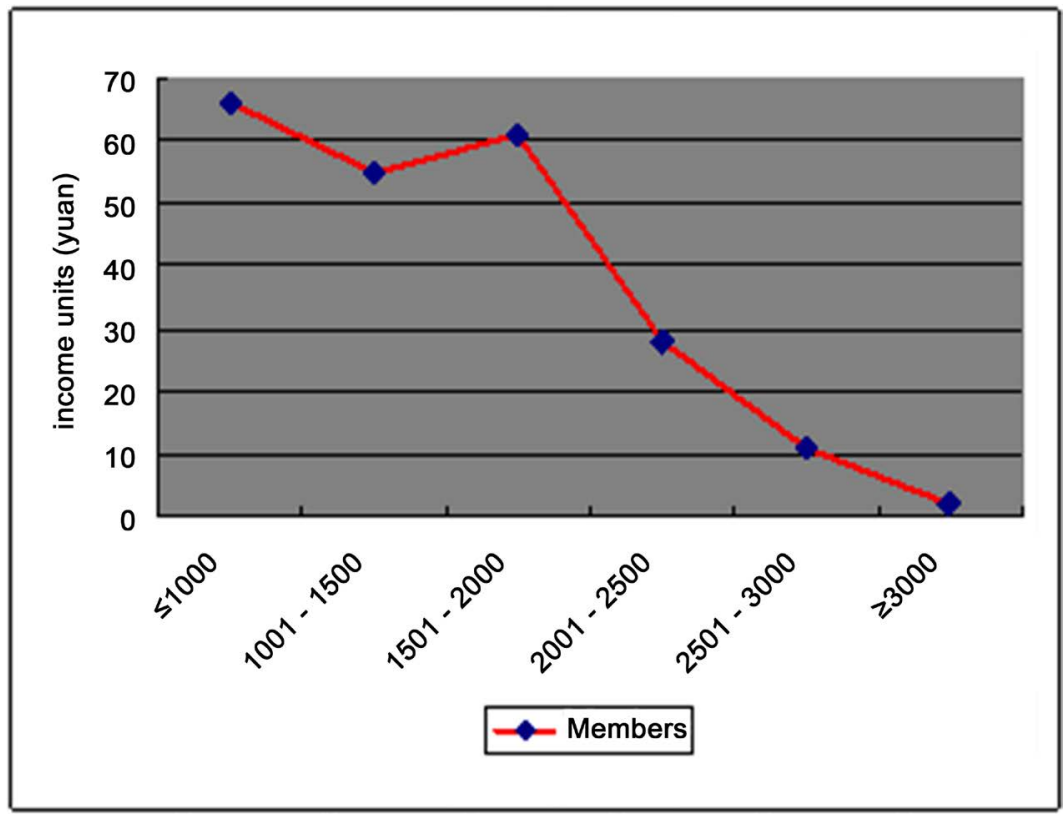

Figure 1. Xinzhou city, Shanxi Province Y village, the villagers' (223) annual income situation.

economy, improve the rural infrastructure construction, improve the rural pension and medical security system, encourage the development of township enterprises, thus promote rural urbanization, in order to improve the rural population income as the breakthrough point, so as to improve farmers' awareness and the concept of democratic participation. As a third party power of government has to play a decisive role in the process of promoting rural economic development, give full play to local advantages, help economically backward regions to realize sustainable development, take the path of scientific development.

3) The interpretation of the "citizens": the lack of powerful supervision

When the phenomenon of unfairness and injustice appeared in rural campaign, the first people who knows is the member of the village committee of perception. Due to the lack of legal knowledge and traditional inertial thinking, farmers solve the problem mainly through the form of letters or direct petition to inform on people of bribery. First of all, concerning "bureaucrats shield one another", farmers have generally low trust in the villages and towns government [5]. They often adopt the form of a petition or complaint in the process of reporting. In addition, for the sake of the resistance of the individual rights, the farmers will take group, and get the attention of superior departments through the power of the group. However, due to the lack of legal knowledge and the bondage of traditional smallholder thought, the reasonable whistle blowing of farmers often become illegal collective behavior. Some are holding the mentality of making a profit rather than for a kind of the sense of justice. Gustave Le Bon said such groups tend to be a bunch of fragile "crowd" [6]. Second, another important reason that cause the failure to prohibition vote buying is the local farmers' rights consciousness is weak. In our interviewed to Baotou city $\mathrm{G}$ village, 40 villagers, 34 villagers believed that the village committee election is a formal process, for the last village officials are basi- 
cally "the most popular family in the village", or "get rich" in recent years or "have authority in the villages and towns government", the villagers who hold this view have low participation to village official campaign, but they hate the unfair which vote buying leads to, but for powerlessness themselves, and at the same time they are most likely to be "the bribee".

\section{Comment on the above Governance Paths of Rural Bribery}

Rural bribery restricts the pace of rural democratic governance, according to the above some reasons about the rural bribery troubled, Chinese scholars has carried on the empirical research about the specific problems of the rural election, and made some countermeasures. They claims from the aspects of normative legal system as a breakthrough point, or from the aspects of developing rural economy, increasing farmers' income, or improve the law or the consciousness of the citizen as the starting point to improve the rural social citizens. In order to seeking rural governance mode and realize the democracy at the grassroots level, safeguard social cohesion, build a new socialist countryside, it is significance to clear up and explore the paths of rural bribery, and analyze and evaluate the advantages and disadvantages between them.

1) Seeking the path of institutional eradication: Ignore the objective necessity

Because the law has loophole, some people put forward to perfect the legal system, improving the villagers autonomy from the perspective of system science. For a long time, some scholars advocate to build the electoral law, system, and hope perfecting the village committee election process through strengthening legislation. They claims defining the concept of vote-buying in the form of legislative interpretation, establishing the public and institutional examine of selection of public funds in the electoral law [5], in order to realise the fairness, justice and open characteristics of electoral competition through a healthy legal system.

First of all, the village committee acts as an autonomous mass organizations at the grass-roots level in rural areas, its decisions tend to be produced by negotiation or the members of the vote, the village committees' decision must be responsible for the villagers' meeting. The function of village meeting can point to a kind of "procedural justice", which holds that a legitimate election process effects the villagers attitude and behavior after fishing the completion of the election. Accordingly, he also believes the result is fair and justice under this program. On the contrary, if it is "go through the motions" that lack due process to guarantee, it will lead to a series of disputes.

Second, if from the perspective of public choice theory, vote-buying has a certain inevitability, it appears with democratic politics [7]. So it can't eradicate vote-buying only through perfecting the system. The founder of the public choice theory, buchanan, from the framework of trade economics, thought the public organization's decisionmaking process as an "economic trade", he researched and described spolitical theme on the market behavior and market operation with the basic hypothesis of new classical economics, the principle and method for the analysis [8]. He thought that the person in the political process is a "rational-economic man" who also seeks their own maximum 
interests, in the village committee election, a candidate is this kind of "rational-economic man", they participate in the elections are holding different, but are selfish motive, in this process, as long as it is conducive to the behavior of "votes" that will be adopted, vote-buying is inevitable. Therefore, it can be said that as long as there is a similar "market" in the process of the village committee election, vote-buying will appear. So, eradicating the phenomenon of bribery in rural governance only through simple legislation or perfecting the system will fell itself into a kind of contradictions and difficulties. Moreover, vigorously promoting the law and moral, and improving the farmers' legal consciousness in rural area, seems to produce another contradiction that is the measure of the law-abiding costs and benefits. Whether individual obedies on system does not depend on whether the system is complete or not. "A persons' behavior choice in any particular case depends on how he knows, views and evaluates the benefits and costs of behavior and its connection with the results." [9] If in a region, civic law-abiding costs significantly higher than the benefits, so citizens generally will choose to break the law, or not to obey the law, if the law-abiding costs equal to the benefits or less than the benefit, then the citizens will generally choose to obey the law [10]. This is why our country still appeared a lot of the phenomenon of illegal election, even if our country vigorously strengthens the rural franco-prussian education propaganda in recent years. Therefore, based on the above some objective reasons, perfecting the legal system can eliminate some non-standard problems arising in the rural autonomy, but if we want to eradicate the problem of rural bribery, it still exist certain difficulties, that no matter from theory and practice is proved to be difficult to achieve.

2) Traditional economic relief mode: The path dependence of history

Backward economy leads to the imbalance of superstructure, it can be corrected by promoting economic development. One important reason is that many rural areas in our country can't make a breakthrough through their own efforts after long-term poverty and backwardness, majority realize development depending on the state power of third party. The advantage of it is the backward villages can be gained all kinds of resources that developing the economy needs in a short period of time, and more significantly effect can be achieved. But the disadvantage are that rural falls into the traditional pattern of relief, and distorts grassroots autonomy.

In our country, village-level cadre is elected by the villagers, and it is one of the main performance of the villagers' autonomy. The promulgated of Organic Law of Village Committees marked the dissolution of township and village administrative subordination relations, realised an autonomous in political and legal sense, the village level organization has no responsibility and obligation to the township administrative organization, only on the working relationship, the village level organization has to support and help accomplish organization issued of township-government [11].

Nevertheless, now in the context of the country, the old implicit obedience-the relationship of command in the village committee and the administrative department is still exist. On the one hand, the local level administrative units intervenes "Fall within the scope of the villager autonomy in accordance with the law" by bright or dark ways, 
especially in some villages under the condition of economy is heavily dependent on local government, part of the township and village leaders designate or appoint the next village leaders (village head, party branch secretary) to muscle into the rural democratic decision-making, manage and supervise and restrict the election litigation channel, it is a disguised form to act the village committee as rural grass-roots units that has the nature of the state power, or act the village committee as sending agencies of the town government [12]. Back to its causes, the first is the administrative leadership of longterm relationship still drives the management of some of the local party and government leadership; Moreover is involved in a contradiction that is competition between local interests and resource competition under the new situation. On the other hand, basing on the deep level regulation model that China's economic and political rely on for a long time, makes the broad masses of peasants have serious "path dependence" in the process of implementation of democracy at the grassroots level.

Path dependence. With the spread of North's theory of institutional change, path dependence become another important view to look at the current problems in domestic academic circles. In simple terms, North thought there is a specific path in institutional changes, the deep history has a very important role on change of system [13].

3) Seeking solutions of social capital: A paradigm

The social capital theory is a very fashionable way in recent years within several mainstream interpretation of rural bribery this paper,. It thought the explanation that it is our country rural lacks social capital stock that leads to the plight of rural governance is a compelling. In the countryside, the backward education and weak tradition of democratic culture leaded to the participation of farmers' autonomy consciousness, historical deposition smallholder thought hindered the formation of social networks, all these leaded to vote buying in rural areas existing for a long time, and become the factors that restrict the course of democratic autonomy.

Contemporary scholars, Robert D. Putnam and Larry Diamond represented by a group of scholars, vigorously promoting the social capital plays an important part in social development, especially in promoting the development and prosperity of a country or region economic and democratic aspects play a huge role. Robert D. Putnam professor thought reciprocity, trust and participation network constitute an important dimension of social capital, it is also an important index to measure the social capital stock. Diamond thought civil association educated the public, it promoted the society develop to the goal of more freedom and autonomy, and made citizens respect state and actively participate in state affairs. Two of them proved their judgment by tight experience arguments and reasoning. In a word, rich social capital can promote social justice and democracy movement, and full of public spirit of citizens will fight with a series of hindrance phenomenon of freedom, so, it also can effectively prevent the happening of the rural bribery [14]. Domestic scholars have tried to through the study of rural capital helps in the understanding and promote the status of rural governance, and puts forward improvement suggestions and countermeasures, trying to lay a foundation for building a new socialist countryside [15]. 


\section{Analysis and Conclusion}

Rural autonomy in China has carried out for decades, and the systems of democracy have taken root in China's rural village. The phenomenon of rural bribery leads to the stagnation or even retrogradation in part of the rich rural autonomy; some relatively poor countries are poorer and weaker, and become one of the main obstacles of people as the masters of their own country in the new period. From the end of last century, there were many articles about rural bribery. By integrating the cause of rural bribery and for reasons of the proposed countermeasures of various scholars, this paper tried to make an induction through a comprehensive perspective, and then analyzed the feasibility of different solutions and defects, in order to do a little research about rural grassroots democracy autonomy in the new period of our country.

Through the above analysis, we learn that the occurrence of rural bribery is a kind of objective necessity; there are plights of theory and practice on governance; namely, it is impossible to eradicate in the political market and democracy development stage. Hence, some people are in gloomy mood, even advocate canceling grassroots autonomy system. Elinor Ostrom said in The Management of Public Affairs, "Any policy based on the metaphor may be harmful". The established theoretical framework and preconceived assumptions may prevent us from advancing in reality. Through theoretical and empirical research, even though we cannot fundamentally eliminate the obstruction that rural bribery causes in the democratization process, we can reduce the interference through comprehensive governance approaches in many aspects, thereby controlling the hazard in the smallest scope. First of all, since the reasonable system standard can produce beneficial behavior, then we can realize the standardization and legalization of rural election by continuously perfecting the legal system, and establish perfect and reasonable rules and regulations. Secondly, from the political and economic relations theory aspects, since rural unreasonable economic structure and poor economic conditions have become the cause that rural bribery occurs, then we can narrow the gap between urban and rural areas, vigorously develop the rural economy, promote the implementation of the support agriculture and the benefiting-farmers policy, gradually reduce the potential recipient of rural bribery, and pay attention to realize the positive interaction between the party and government organs, administrative management and the villagers' autonomy in the process of rural urbanization. Finally, based on the role of social capital for the western democratic society, on the one hand, we should speed up the construction of harmonious rural, raise farmers' cultural quality, and enrich rural community activities; on the other hand, we also need to maintain the stability of rural life, and prevent the deformity development of rural association.

\section{References}

[1] Hou, J.H. (2004) The Standardization Problems in the Process of the Villagers' Autonomy and Coping Strategies. Academic Exploration, No. 2, 10-13.

[2] Economic Daily News (2005) Standardize the Competition of the Village Committee Elections, the Definition of Vote Buying by Ministry of Civil Affairs. 
[3] Williamson, O. (2002) The Capitalist Economic System. The Commercial Press.

[4] Li, Y.Y. (2008) Analysing the Causes and Countermeasures of Rural Phenomenon of Bribery. Economic and Social Development, No. 5, 102.

[5] Hu, D.F. (2011) Social Capital and Rural Governance. Science, Economy, Society, No. 2, 81-87.

[6] Le Bon, G. (2015) THE CROWD: A Study of the Popular Mind. China Legal System Publishing House, Beijing.

[7] Zhou, H. (2008) The Definition of Vote Buying and Perfecting the Legislation. Journal of Kunming University of Science and Technology Social Sciences (Law), No. 11, 19-23.

[8] Hu, J.F. and Zhang, H.F. (2003) The Objective Reasons and Countermeasures of the Phenomenon of Vote Buying in Rural Grassroots Democratic Elections. Sun Yat-sen University Graduate Student Journal (Social Science Edition), No. 1, 81-88.

[9] Fang, F.Q. (2000) Public Choice Theory-Economics of Politics. China Renmin University Press, Beijing.

[10] Ostrom, E. (2013) Governing the Commons-The Evolution of the System of Collective Action. Shanghai Translation Publishing House, Shanghai.

[11] Han, D. (2009) Institutional Analysis of China's Rural Phenomenon of Vote Buying. Shandong University, Jinan.

[12] Liu, J.H. (2000) The Performance Evaluation of Villager Autonomy. Socialism Studies, No. 2, 64-67.

[13] Hou, J.H. (2004) The Standardization Problems in the Process of the Villagers' Autonomy and Coping Strategies. Academic Exploration, No. 2, 10-13.

[14] North, D.C. (1994) Institutions, Institutional Change and Economic Performance. Liu, S.Y., Trans., Shanghai Sanlian Bookstore, Shanghai.

[15] Putnam, R.D. (2011) Bowling Alone-The Decline and Revival of American Community. Peking University Press, Beijing.

\section{Submit or recommend next manuscript to SCIRP and we will provide best service} for you:

Accepting pre-submission inquiries through Email, Facebook, LinkedIn, Twitter, etc.

A wide selection of journals (inclusive of 9 subjects, more than 200 journals)

Providing 24-hour high-quality service

User-friendly online submission system

Fair and swift peer-review system

Efficient typesetting and proofreading procedure

Display of the result of downloads and visits, as well as the number of cited articles

Maximum dissemination of your research work

Submit your manuscript at: http://papersubmission.scirp.org/

Or contact jhrss@scirp.org 